\title{
DETERMINANTS OF SHARIAH BANKING PERFORMANCES IN INDONESIA THROUGH THE PERSPECTIVE OF ECONOMIC AND SOCIAL LEVEL
}

\author{
Helma Malini* \\ Universitas Tanjungpura, Indonesia
}

\begin{abstract}
Shariah bank has become the core of Indonesia financial industry. In the implementation, Shariah banking in Indonesia is integrated with social issues since the basic fundamental of Shariah banking industry are from religions and regulations. In detail the return are not solely depends on society demand but also related with moral issues. As corruption that kept on happening and political instability makes Shariah Banking industry in Indonesia sensitive and fragile towards socio economic development happening during certain period. This paper attempt to investigate the socio economic factors together with bank specific factors of Indonesia Shariah Banks by using GMM and Quantile regression. The dataset used or in this study involves 34 Shariah banks in Indonesia. In this study, Return on Assets has been found significantly positive to bank specific factors such as credit risk and statistically negative to cost to income ratio. However, it has been found that the relationship between risk and return is heterogenous or dissimilar accross different quantiles. Findings of the study tend to reveal that the socio economic factors particularly corruption, political stability and investment freedom have positive and significant relation to the Shariah bank performances in Indonesia.
\end{abstract}

JEL : G2, E5.

Keywords: performance, achievement, socio-economic development, credit risk, dynamic gmm, quantile regression.

\section{INTRODUCTION}

Indonesia under the dual financial system has the most severe exposure toward the instability and imbalances that creates by financial crisis and the faltering of money market due to the relatively high linkages of dual banking system. The linkages expose Shariah banks in Indonesia. The macroprudential framework that implemented in Indonesia banking currently does not gives a guarantee that Shariah banks will have more resilient toward financial crisis and other shock. However, the interconnectedness between Shariah and conventional bank under dual financial system will trigger policy clashes between regulation and religion since both of them have different objectives. Unlike the conventional banks, Shariah banks promote risk sharing principles by using many investment tools such as Mudarabah and Musharakah (Ahmed, 2011).

Due to the dynamism of different contracts, it is generally perceived that the risk is comparatively higher in Shariah banks compared to their conventional counterparts. It is usually argued that Shariah Banks have higher degree of credit risks than interest-based banks mainly because of their nature of trade based investment. The current development of Shariah Banks keeps on improving; these facts can be concluded from the performance of Shariah Banking assets positions that recorded to grew by $20.65 \%$ on an annual basis of 2018 . This development supported with the increase of Shariah commercial bank offices, as well as Shariah business

\footnotetext{
*Email : helmamalini@yahoo.com

Received : 17-07-2019, Accepted : 12-08-2019, Published : 28-04-2020.

P-ISSN : 2087-9954, E-ISSN : 2550-0066. DOI : http://dx.doi.org/10.26418/jebik.v9i1.34327
} 
units, another suporting performance is the capital from Shariah banks that categorized as "good" shown by the Islamic CAR ratio of $18.62 \%$, while the growth of Shariah bank customers rose by 18.05 per year, and "Otoritas Jasa Keuangan" Indonesia (Financial Services Authority) stated that compared to conventional banks that only reached 14\%, 4-5\% lowers than Shariah banks. The development shown a significant development; however, the growth of Islamic finance has not been able to keep up with conventional financial growth

In the implementation, risk sharing is a unique concept that enable investor to share risk. However, the concept of risk sharing and its implementation still far from what its expect to be. The concept of "Maqasid al Shariah" depends solely on fairness however this concepts heavily depends on good corporate governance, fairness, transparancy and accountability. Corruption in Indonesia are no getting better and still exist among public officials and politicians, this fact can be translated that level of transparancy also depend on the index of corruption as well.

In the future, dual banking system will have potential risk due to expose of failures in macro policy, market and regulation in Indonesia. Macroprudential supervisory to sustaining financial system stability from risk exposure will have significantly role for financial system in Indonesia. In summary, the clashes between regulation and religion will expose challenges to Shariah banking in Indonesia in formulating and implementing regulation since it will have mismatch with religion. There is a wide argument that Shariah bank assets should not based on debt transaction such as murabaha and ijara (Yousef, 2004). On the contrary, Chapra (2007) argues that the share of equity based transactions should be significant part in Shariah banking system.

Several studies have assessed performance conditions in Indonesia the banking industry where the Islamic banks are in competition with conventional banks. This study contributes to the literature by comprehensively performance of the Islamic banking in Indonesia. The international financial crisis including domestic shock could have an impact on the performances of the system. This study thus examines the performances of Islamic banks in Indonesia by identifying the factors that express market power for banks to in term of Economic and Social Level.

Chapra (2007) defined Shariah banking risk profile into two; generic risk and unique risk profiles. Generic risk is the risk exposures of Shariah banking activities such as credit risk, market risk, liquidity and operational risk. While, unique risk is defined as the unique risk exposure of Shariah banking operationalization which include Shariah non compliance risk, rate of return risk, displaced commercial risk, equity investment and inventory risk. Unique and general risk in the process influence by several factors including demography and socio economic factors. In the implementation, Shariah banking is more resilient toward general risk since the expose of general risk seldom happened in conventional banking due to its financing activities. Meanwhile, the dynamism of Indonesia demography and socio economic factors will contribute to the increase of both risk for Shariah banking industry in Indonesia.

Social and economic development contribute significant role in Shariah banking industry, the definition of social and economic development that widely accepted is social and economic development process in society. Socio economic development are measures with indicators such as GDP, life expectancy, literacy, levels of employment, freedom of association, personal safety and freedom from fear of physical harm and the extent of participation in civil 
society. However, it is going to be difficult to maintaining and balancing socio economic development and its influence the performance of Shariah banks in Indonesia. Since, Shariah banks must segregate their investment activities with Shariah principle that comes from religion while social economic development in Indonesia keeps changing and dynamics that eventually influence Indonesia Shariah banks (Anto \& Wibowo, 2013).

The existing literature mostly provides empirical evidence on the existing performance in conventional banks and focuses on interest based. As the growth of Shariah bank in Indonesia increase over the last eleven years, which indicates that most of investors already aware of the Shariah banking industry. This reason along with significant growth of market share makes the performances measurement of Shariah banks in Indonesia are very important to conduct. This research have two significant contribution, it will provide special treatment for the Shariah banks in one side and realize the core concepts of Shariah principle regulation and decide what is the best concept for Shariah principle in the future in order to achieve efficient market in term of fairness, transparency, protection to investor and reducing systematic risk by finding the impact of bank specific variables and socio-economic freedom on Shariah banks profitability in Indonesia and by finding whether risk-return relationship across different percentiles is similar or not in terms of bank specific and socio-economic freedom variables.

\section{LITERATURE REVIEW}

Zeitun (2012) examines factor influencing Islamic banks and conventional banks in the perspective of foreign ownership, bank specific variables and macroeconomic variable. The finding showed that equity was the most important variable in detrmining the profitability of Shariah banks while the size of the banks that supported the economics of scale supporting the ROE of Shariah banks. The characteristics of Shariah banks operation is based on partnership and mutula benefit principle to provide an alternative banking system for the public. On the contrary, GDP was found to be positively related while inflation negatively related to the banks performances both to Shariah and conventional bank industry. If we take a look back at previous research of Shariah bank performances than study from (Kuppusamy, 2010) using the Shariah conformity and profitability model whereas the research focusing on the external factors of Shariah banks that contributes also to the performances and continuity of Shariah bank are socio economic development.

Despite, rare research using external factors, Anto \& Wibowo (2013) and Zulifiah (2014) measuring inflation and interest rate as external factors and finds that there are no correlation between interest rate and profitability. A study that conducted by Khediri et al. (2015) showed that Shariah bank is less risky and more solvent due to the ability to adapt with the exposure of internal variables and economic environment. However, this result needs to be proven further if the environment is changing and faced many volatilities due to policies from government. On the contrary, study from Wasiuzzaman and Gunasegavan (2013) showed that internal factors influence Shariah bank performances in term of assets size, asset ratio and Shariah bank management efficiency effects capital adequacy and profitability. The findings also suggesting that Shariah banks should rely to develop bank management efficiency since it is relates with their core concept of transparancy and fairness.

Several previous studies about Shariah banking performance using debt, equity, assets, bank management and efficieny to measure the performances while studies that using social and 
economic variable are used only to measures economic growth in general and its impact toward Shariah banking that conducted by powel (Powell, 2002) reveals how economic policies influence economic growth in one country, particularly on government involvement in economy and how freeing private entrepreneues and investor to pursue their own self interest will give benefit to many sectors growth including banking.

Despite numerous research on socio economic perspective, there are only few studies that linked the socio economic perspective with economic growth, one of them is study from Chin and Ito (2007) that assess social and economic grwoth impacted to the account balances of one country where legal system and open financial markets are keys to achieve the balance. On the contrary, social and economic growth has been extensively used in research for different context, including for determinant analysis of Islamic financial growth. In general, further study needs to conduct for future potensial and growth of the financial industry in Indonesia that will help to strenghten Shariah banking industry in particular.

\section{RESEARCH METHODS}

\subsection{Data Collection}

Data used in this research are collected from 34 unit of Shariah banks in Indonesia (including the conventional bank who opened Shariah banks unit) through Bank data, Indonesian Central bank and IMF research database over the period 2010-2018. Financial statements of Shariah bank that operates in Indonesia are collected from each bank financial report. The socio economic data such as rule of law, property rights, corruption, investment freedom and political stability collected from world bank and IMF financial statistics (IFS) database.

Table 1. Variables Measurement

\begin{tabular}{|c|c|c|}
\hline Variable & Definition & Description \\
\hline CIR & Cost to Income Ratio & $\begin{array}{l}\text { It refers the operational efficiency of } \\
\text { firm }\end{array}$ \\
\hline SZ & Bank Size & Natural Log of Total Asset \\
\hline IF & Investment Freedom & The Investment Freedom Index $(0-100)$ \\
\hline PR & Profitability of Banks & Return on Assets (ROA) \\
\hline CPI & Corruption Perception Index & $\begin{array}{l}\text { Ranges from } 1 \text { (most corrupt) to } 10 \\
\text { (least corrupt) }\end{array}$ \\
\hline LLRGL & Credit Risk & Loan Loss Provision \\
\hline POLS & Political Stability & $\begin{array}{l}\begin{array}{l}\text { Ranges from } \\
\text { (strong) }\end{array} \\
\text {-25 (weak) to } 2.59\end{array}$ \\
\hline
\end{tabular}

\subsection{Methodologies}

In line with the extent literature, this research use both static model where dynamic model also applied to make sure the determinant factors will be estimated efficiently where a combination between static model and dynamic model will gives exact estimation to the compounding effect of a one time shock over years.

\section{Static Models (Fixed and Random Effects):}

The panel data is used in analyzing the bank's portability determinants. In the panel data, the used model consists $n$ cross-sectional units, denoted $n=1, \ldots, N$, observed at each of $T$ time periods, $\mathrm{t}=1, \ldots, \mathrm{T}$. In data set, the total observation is $\mathrm{n} \times \mathrm{T}$. The basic framework for the panel data is defined as per the following regression model (Bikker, 2002): 


$$
Y n t=a+\beta X n t+n t
$$

Where the dependent variable (Profitability) denoted by Ynt . Interecept term used and dentoted by a, on the explanatory variables, $\beta$ is a $\mathrm{k} \times 1$ vector of parameter to be estimated, and vecor of observations is $\mathrm{Xnt}$ which is $1 \times \mathrm{k}, \mathrm{t}=1, \ldots \ldots \mathrm{T} ; \mathrm{n}=1, \ldots \ldots \mathrm{N}$.

Econometric specifications:

$$
R O A=a+\beta 1 C I R+\beta 2 L T A+\beta 3 L L R G L+\beta 4 C O R+\beta 5 I F L+\beta 6 P R+\varepsilon
$$

Here, Y represents the dependent variable Return on assets (ROA). Independent variables:

$\begin{array}{ll}\text { CIR } & =\text { Cost to income ratio, } \\ L T A & =\text { Natural log of Total asset } \\ \text { LLRGL } & =\text { Loan loss reserve/ Gross loan } \\ \text { COR } & =\text { Corruption } \\ P O L S & =\text { Political stability } \\ I F & =\text { Investment freedom } \\ P R & =\text { property rights } \\ \varepsilon & =\text { Error term }\end{array}$

\section{Dynamic GMM models:}

Extensive empirical research in banking industry implies that fixed and random effects apply for panel data. However, consistency of bank profitability will influence next year profit resulting into problems and difficulties that will arises when a lagged dependent variable or possible other regressor is concerned during certain time period of observations. To overcome this problem, Arellano and Bond (1991) develop the difference GMM (Gaussian Mixture Model) model by differencing all regressors and employing GMM (Hansen, 1982).

\section{Quantile Regression (QR) model:}

This study employs a QR model in which the parameter of explanatory variables can be expressed as a monotone function of a single random variable. The model captures systematic influences of conditioning variables on location, scale and shape of the conditional distribution of the response. The model is thus significantly extended with a constant coefficient in which the effects of conditioning are confined to a location shift. Furthermore, this study reveals that traditional optimization techniques, including OLS and LAD, disregard different behaviors in the tail regions of bank profitability distributions and the risk -return relationships in banks change in the tail regions.

Following this line of thought, a QR technique that used in this study to examine the dynamic relationship between the risk and bank profitability performance. Assuming that the 9 th quantile of the conditional distribution of the explained variable is linear in $\mathrm{x}$ where Quant $\mathrm{Xi}$, the conditional QR model can be expressed as follows:

$$
\begin{gathered}
Y_{i}=x_{I}^{\prime} . \beta_{\theta}+u_{\theta I} \\
\text { Quante }_{\theta}\left(y_{i} / x_{i}\right)= \\
\inf \left\{y: F_{i}(y / x) \theta\right\}=x_{i .}^{\prime} \beta_{\theta} \\
\text { Quante }_{\theta}\left(u_{\theta i}\left(x_{i}\right)=0\right.
\end{gathered}
$$


where Quant ${ }_{\theta}\left(\mathrm{y}_{\mathrm{i}} \mid \mathrm{x}_{\mathrm{i}}\right)$ represents the $\theta$ the conditional quantile of $\mathrm{y}_{\mathrm{i}}$ on the regressor vector $\mathrm{x}_{\mathrm{i}} ; \beta_{\theta}$ is the unknown vector of parameters to be estimated for different values of $\theta$ in $(0,1)$; $\mathrm{u}_{\theta \mathrm{i}}$ is the error term assumed to be continuously differentiable c.d.f. (cumulative density function) of $F,(y \mid x) \theta$ and a density function $\mathrm{F}_{\mathrm{i}}(\mathrm{y} \mid \mathrm{x}) \theta$. The value $\mathrm{F}_{\mathrm{i}}(\mathrm{y} \mid \mathrm{x}) \theta$ denotes the conditional distribution of $\mathrm{y}$ conditional on $\mathrm{x}$. Varying the value of $\mathrm{u}$ from 0 to 1 reveals the entire distribution of $\mathrm{y}$ conditional on $\mathrm{x}$. The estimator for $\mathrm{b} \mathrm{u}$ is obtained from

$$
\begin{gathered}
\min \sum_{\mathrm{i}: u \theta \geq 0}^{\mathrm{n}} \theta^{\mathrm{x}}|u \theta|+\sum_{\mathrm{i}: \mathrm{u} \theta \leq 0}^{\mathrm{n}} 1-\theta^{\mathrm{x}}|\mathrm{u} \theta \mathrm{i}| \\
=\sum_{i: y i-x^{\prime} i . \beta \theta \geq 0} \theta^{x}\left|y i-x^{\prime} i . \beta \theta\right|+\sum_{i: y i-x^{\prime} i . \beta \theta \leq 0}(1-\theta)^{x}\left|y i-x^{\prime} i . \beta \theta\right|
\end{gathered}
$$

\section{RESULT AND DISCUSSION}

\subsection{Descriptive Study}

This chapter discusses the result of the test and followed by the analysis. Table 2 presents descriptive statistics for the profitability (ROA) and the bank-specific and macroeconomic variables used in our model. In average, the return on average asset of 34 Shariah banks used in this study is 1.07 . The mean of all other independent variables are also positive except Political stability.

In terms of socio economic perspectives, the average mean of political stability is positive means that it is highly contributing to the performances of Shariah banks. Political dynamism contributing to risk exposure of Shariah banks since one of the consideration for investor to investor in investment portfolio including Shariah banking is sense of security that translate into political stability. Cost to income ratio mean is (78.4321) translates as the comparison between cost to income of Shariah banks in average were varies greatly where there is no comparison between private and state own Shariah banks. Cost to income ratio in Shariah banks achieved when Shariah banks can perform by maximizing the using of its asset that mainly consist of customer saving.

Table 2. Descriptive Statistics of the Variables used in the Empirical Analysis

\begin{tabular}{lrrrrrrrr}
\hline Item & \multicolumn{1}{c}{ ROA } & \multicolumn{1}{c}{ CIR } & \multicolumn{1}{c}{ LTA } & LLRGL & \multicolumn{1}{c}{ COR } & \multicolumn{1}{c}{ POLS } & \multicolumn{1}{c}{ IF } & PR \\
\hline Mean & 1.0786 & 78.4321 & 14.6055 & 8.57324 & 0.03972 & 0.2145 & 45.500 & 45.863 \\
Median & 1.1750 & 50.8800 & 14.8930 & 3.55500 & 0.06000 & -0.3700 & 45.000 & 50.000 \\
Max & 17.7800 & 789.240 & 18.1281 & 100.000 & 1.72000 & 1.36000 & 90.000 & 90.000 \\
Mean & -23.6600 & 13.4000 & 10.7166 & 0.00000 & -1.5700 & -2.6900 & 0.0000 & 10.000 \\
Std & 1.29320 & 66.3451 & 1.4638 & 12.1174 & 0.8463 & 1.6382 & 10.653 & 11.243 \\
Deviation & & & & & & & & \\
Skewness & -1.89712 & 5.23403 & -0.2426 & 3.81701 & 0.01808 & -0.3918 & 0.226 & 0.3597 \\
Kurtosis & 8.6890 & 3.7654 & 1.7689 & 1.4220 & 5.7654 & 9.9654 & 6.2867 & 13.8795 \\
Observations & 220330 & 220330 & 220330 & 220330 & 220330 & 220330 & 220330 & 220330 \\
\hline
\end{tabular}

Notes: The dependent variable is ROA is calculated as net profit divided by total assets. CIR-the cost to income ratio is used as a proxy for operating efficiency. LLP/TL is a measure of credit risk calculated as the ratio of total loan loss provisions by total assets. LOG TA is a proxy measure of size, calculated as a natural logarithm of total bank assets. POL measures the political stability. IF indicates the Investment freedom and PR refers the Property rights.

Highest standard deviation value is (12.1174) at LLRGL that translated to credit risk, in Shariah banking industry contributes major risk in performance achievement since most of the 
financing fund that applied by Shariah banks is credit transfer in form of Murabahah and Musyarakah. In the implementation, Murabahah and Musyarakah have its own risk where in general the risk came from difficulties to pay the credit fund. The highest kurtosis in the sample occurs in PR (Profitabity of Banks). However, if kurtosis in one country exceeds the threshold of 3 , implying that the returns have fatter tails than would be expected from a normally distributed variable, where Shariah banks in Indonesia are profitable in general but the circumstances depends on many factors including the domination in Shariah banking market share.

\subsection{Correlation Matrix}

Risk sharing is a unique concept that enable investor to share risk. However, the concept of risk sharing and its implementation still far from what its expect to be. The concept of "Maqasid al Shariah" depends solely on fairness however this concepts heavily depends on good corporate governance, fairness, transparancy and accountability.

Table 3. Correlation Matrix

\begin{tabular}{lllllllll}
\hline & LLRGL & CIR & ROAA & COR & LTA & PR & POLS & IF \\
\hline LLRGL & 1.000 & & & & & & & \\
CIR & 0.6155 & 1.000 & & & & & & \\
ROAA & 0.6453 & 0.4302 & 1.000 & & & & & \\
COR & 0.4839 & 0.3124 & 0.3413 & 1.000 & & & & \\
& & & & & & & \\
LTA & 0.4849 & 0.2412 & 0.4531 & -0.765 & 1.000 & & & \\
PR & 0.3920 & -0.2221 & -0.4561 & 0.876 & 0.5323 & 1.000 & & \\
POLS & 0.4839 & 0.4315 & 0.7894 & 0.0211 & 0.3323 & 1.1686 & 1.000 & \\
IF & 0.5362 & 0.5432 & 0.0003 & 0.0743 & 0.5021 & 9.0519 & 0.765 & 1.000 \\
\hline
\end{tabular}

Notes: The dependent variable is ROA is calculated as net profit divided by total assets. CIR-the cost to income ratio is used as a proxy for operating efficiency. LLP/TL is a measure of credit risk calculated as the ratio of total loan loss provisions by total assets. LOG TA is a proxy measure of size, calculated as a natural logarithm of total bank assets. POL measures the political stability. IF indicates the Investment freedom and PR refers the Property rights.

Table 3 describes that during period of observation, all the selected variables showed strong correlation to each other as reflected by the strong correlation of coefficients. Strong correlation or the highest value of correlation is recorded between Investment Freedom to profitability (9.0519), followed by political stability to profitability (1.1686). Strong correlation between variables suggest the major factor contributing to the strong correlation are investment freedom and political stability, since variables that correlates to each other came from different value and based on the characteristics of Shariah banks. Furthermore, this part of research does not find any correlation or weak correlation between assets to profitability, indicating that every asset owned by Shariah banks in Indonesia does not influence directly to bank performances.

\subsection{Model Estimations}

Result from the table also describe that at least two variables has significant influence to the performances of Shariah banks which is corruption and political stability. This result can be translated as plausible positive direction of influence where corruption can occur because of government quality will affect investment and economic growth. High level of corruption in one country will also increase high cost economy that will slowing down economic growth and investment (Damanhuri, 2010). Referring to the impact of credit risk, is is found that positive and significant impact on the profitability of Shariah banks even at 5\% significant level. The result implies that every increase and decrease in Shariah bank credit risk will influence the profits of 
Shariah banks and eventually influence the level of competitiveness. Compare with conventional bank where the distribution of credits contrast with their profits since conventional banks have other product in form of credit that they can sell while in Shariah bank the form of credits is binding the customer and Shariah banks to comply on the Shariah principle.

Tabel 4. Model Estimation

\begin{tabular}{lcccc}
\hline \multicolumn{1}{c}{ Variables } & $\begin{array}{c}\text { Fixed } \\
\text { Effects }\end{array}$ & $\begin{array}{c}\text { Random } \\
\text { Effects }\end{array}$ & $\begin{array}{c}\text { 1st step Differenced } \\
\text { GMM }\end{array}$ & $\begin{array}{c}\text { 2nd Step Differenced } \\
\text { GMM }\end{array}$ \\
\hline Intercept & -0.0196 & 0.3576 & 1.2512 & 0.02024 \\
LLRGL & -0.0213 & 0.1183 & -2.8137 & 0.01278 \\
CIR & 0.0031 & 0.3233 & 0.0844 & 0.00872 \\
ROAA & -0.0035 & 0.2238 & -0.2885 & 0.01100 \\
COR & 0.0163 & 0.2396 & 1.0748 & 0.01416 \\
LTA & 0.0509 & 0.2879 & 1.0064 & 0.01395 \\
PR & -0.0081 & 0.1869 & 0.6904 & 0.01286 \\
POLS & 0.0109 & 0.1696 & 0.016 & 0.01931 \\
IF & 0.0251 & 0.3279 & 2.7519 & 0.00986 \\
R-squared & 0.0322 & 0.5692 & 2.9903 & 0.01483 \\
F-stat/ Wald- $\chi^{2}$ & 0.0191 & 0.2545 & 0.6453 & -0.0804 \\
AR(1) test & -0.0046 & 0.1239 & -2.6359 & -0.8530 \\
AR(2) test & 4.2594 & 1.8952 & 2.3908 & 0.3974 \\
No. observations & 220 & 220 & 220 & 220 \\
\hline
\end{tabular}

Notes: The dependent variable is ROA is calculated as net profit divided by total assets. CIR-the cost to income ratio is used as a proxy for operating efficiency. LLP/TL is a measure of credit risk calculated as the ratio of total loan loss provisions by total assets. LOG TA is a proxy measure of size, calculated as a natural logarithm of total bank assets. POL measures the political stability. IF indicates the Investment freedom and PR refers the Property rights. Notes 2 : Values in parenthesis are t statistics, $(* * *),(* *),(*)$ indicates significance at 1,5 , and $10 \%$ level respectively.

The result also confirm that selected variables have positive influence toward the performance of Shariah banks, where political stability and corruption are the major determinants. Demographical condition in Indonesia where political structures becoming significant part of Indonesian society daily lives determines how society perceive politics that eventually leads to trust including in banking sector. In certain case where there is a change in political condition means there is a massive loss of investor confidence.

\subsection{Quantile Regression}

Credit risk for Shariah banks should be perceive at different points since measuring Shariah banks credit risk in one country have to consider and face trade off between regulatory and religious framework (Ahmed, 2011). Table 5 shows the QR result of IBs, the OLS result is not inconsistent with the QR result at different percentiles. Moreover, a comparison of the $\mathrm{QR}$ estimates with the traditional OLS estimates indicates that the OLS estimates underestimate the positive risk- return relationship at the higher quantile levels and obtain the wrong conclusion at the lower quantiles. It has been found that COR, POLS, and IF are important variables at any percentile. The three variables important at any percentile showed that risk sharing in Shariah banking is positive and significantly related to Shariah bank performances. This findings also suggest that Shariah bank specific characteristics through risk sharing principle is major form to increase portfolio and collect funding rather than debt financing. 
Table 5. Quantile Regression at Different Percentiles

\begin{tabular}{ccccc}
\hline & $\begin{array}{c}\text { OLS_res } \\
\text { b/se }\end{array}$ & $\begin{array}{c}\text { Q25_res } \\
\text { b/se }\end{array}$ & $\begin{array}{c}\text { Q50_res } \\
\text { b/se }\end{array}$ & $\begin{array}{c}\text { Q75_res } \\
\text { b/se }\end{array}$ \\
\hline LLRGL & $-0.3286^{*}$ & $0.197(68)$ & $-0.0217 * * *$ & 1.70216 \\
CIR & -0.2359 & 0.835553 & $-0.0196 * * *$ & -.91365 \\
COR & $0.3933^{* *}$ & 0.03990 & 2.4545 & 3.6773 \\
LTA & $-.4268^{*}$ & $-.1393 * * *$ & -.60839 & 0.78052 \\
PR & -0.0126 & $4.7856^{* * *}$ & 0.10345 & 0.39485 \\
POLS & 0.0242 & $6.6729 * * *$ & 0.31578 & 0.23399 \\
IF & 0.0003 & $0.0175^{* * *}$ & 3.72873 & 0.8173 \\
\hline
\end{tabular}

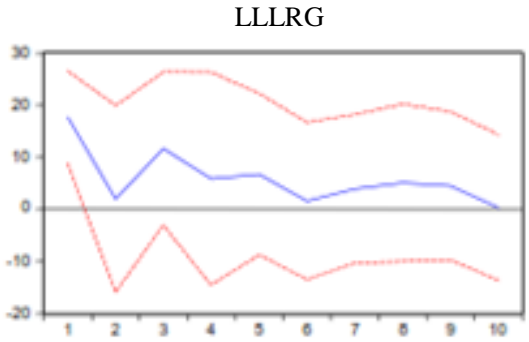

CIR

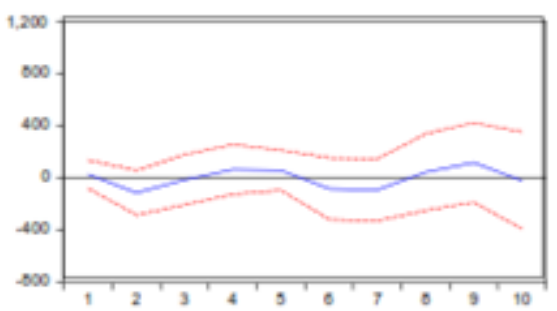

IF

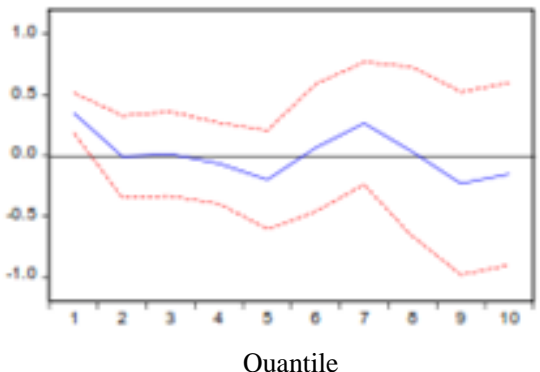

Quantile

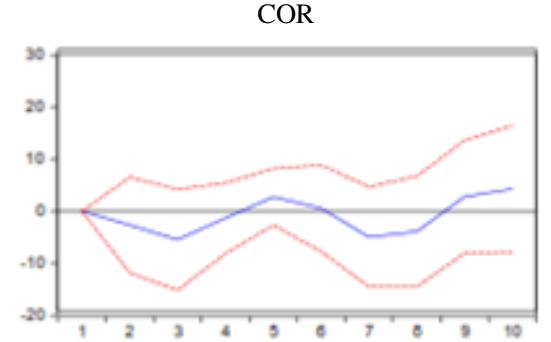

POLS

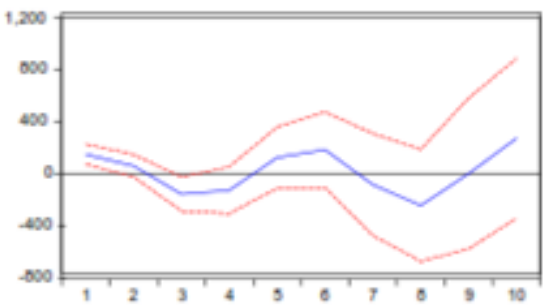

PR

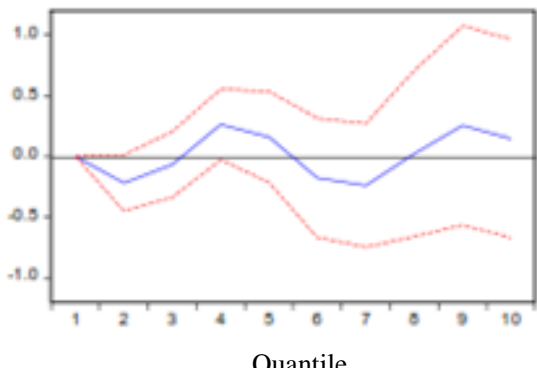

Quantile

Figure 1. Regression lines: QR vs OLS for different variable

Figure 1 represents the regression lines drived by the QR against the OLS method. COR, POLS and IF cross the significance level (upperbound) after a certain level of percentile. The result can be explained relates with portfolio theory; "the higher the risk, the higher the return". However, there are particular sector in banking industry that relates with high cost. High cost for Shariah banking industry initially occur from its original product offering Shariah regulation such as : selling price, ceiling rate, settlement rebate, commodities trading fees and requirements of more document in Shariah banking that leads to the decrease of profits (Karim et al., 2010). From socio economic perspective, the result are consistent except cost to income ratio and property rights, this can be explained as size and number of investor, since several Shariah banks that includes on the sample operates within small capitalization since it is a unit from their conventional bank. 


\section{CONCLUSION}

The implementation of dual banking system in Indonesia has its own benefit and weaknesses. One of the benefit is that government has two kinds of institution in mobilizing fund from public including from the conventional sector where both works hand in hand to improve the capability of financing for the national economy. The characteristics of risk sharing in Shariah banks focus on transaction fairness, ethics investment and avoiding speculative activities in finance transaction that can be achieving by providing banking products that accordance with Shariah principle norm. On the other side, risk sharing principle offer solution with its own problem particularly relates with Indonesia socio economic problems that are changing day by day. This study examined variables that influence Indonesia Shariah banking performances where corruption and political stability contributes strongly to Shariah banking performances where on the original concept of Shariah, corruption views as the action that harm other parties and considered as Haram (Islam law status against one action or products).

This study found that investment freedom creates investment freedom for investor. However, this result should be examined further on whether investment freedom translated into minimum government intervention since dual banking system in Indonesia will make distinctive line between conventional and Shariah banking in order to prevent trade off. Trade off in Shariah banking is something that will significantly occur since the integration between regulation and religion rules is something that leads to the mismatch in implementing Shariah policy with conventional.

\section{REFERENCES}

Ahmed, H. (2011). Maqasid al-Shari'ah and Islamic financial products: a framework for assessment. ISRA International Journal of Islamic Finance, 3(1), 149-160.

Anto, A., \& Wibowo, M. G. (2013). Faktor-faktor Penentu Tingkat Profitabilitas Bank Umum Syariah Di Indonesia. La_Riba: Jurnal Ekonomi Islam, 6(2), 147-160.

Chapra, M. U. (2007). The case against interest: Is it compelling? Thunderbird International Business Review, 49(2), 161-186.

Chinn, M. D. \& Ito, H. (2007). Current Account Balances, Financial Development and Institutions: Assaying the World "Saving Glut". Journal of International Money and Finance 26(4): 546- 569.

Damanhuri DS. (2010). Ekonomi Politik dan Pembangunan: Teori, Kritik, dan Solusi bagi Indonesia dan Negara Berkembang. Bogor: IPB Press.

Hansen, L. P. (1982). Large sample properties of generalized method of moments estimators. Econometrica: Journal of the Econometric Society: 1029-1054.

Karim, B. K., Mohamed Sami, B. A., \& Hichem, B.-K. (2010). Bank-specific, industry-specific and macroeconomic determinants of African Islamic banks' profitability. International Journal of Business and Management Science, 3(1), 39.

Khediri, K. Ben, Charfeddine, L., \& Youssef, S. Ben. (2015). Islamic versus conventional banks in the GCC countries: A comparative study using classification techniques. Research in International Business and Finance, 33, 75-98. 
Kuppusamy, M. d. (2010). Measurement of Islamic Banks Performance Using a Shariah Conformity Measurement of Islamic Banks Performance Using a Shariah Conformity and Profitablity Model. Jurnal Review of Islamic Economics, 13, 35-48.

Powell, B. (2002). Economic freedom and growth: the case of the Celtic tiger. Cato J., 22, 431.

The Heritage Foundation. (2019). Index of Economic Freedom

Transparancy International. (2016). https://www.transparency.org/news/feature/corruption_perceptions_index_2016

Yousef, T. M. (2004). The Murabaha syndrome in Islamic finance: laws, institutions and politics. The Politics of Islamic Finance, 63-80.

Zeitun, R. (2012). Determinants of Islamic and conventional banks performance in GCC countries using panel data analysis. Global Economy and Finance Journal, 5(1), 53-72.

Zulifiah, F. (2014). Pengaruh Inflasi, BI Rate, Capital Adequacy Ratio (CAR), Non Performing Finance (NPF), Biaya Operasiona dan Pendapatan Operasiona (BOPO) Terhadap Profitabilitas Bank Umum Syariah Periode 2008-2012. Jurnal Ilmu Manajemen (JIM), 2(3).

Wasiuzzaman, S. \& Gunasegavan, U.N. (2013). Comparative study of the performance of Islamic and conventional banks: The case of Malaysia. Humanomics 29(1): 4360. 